\title{
Integrating Functions for a Sustainable Urban System: A Review of Multifunctional Land Use and Circular Urban Metabolism
}

\author{
Saskia van Broekhoven ${ }^{1,2, *}$ and Anne Lorène Vernay ${ }^{3}$ \\ 1 Department of Public Administration and Sociology, Erasmus University, Burgemeester Oudlaan 50, \\ 3062 PA Rotterdam, The Netherlands \\ 2 PBL Netherlands Environmental Assessment Agency, Bezuidenhoutseweg 30, \\ 2594 AV The Hague, The Netherlands \\ 3 Grenoble Ecole de Management, Univ Grenoble Alpes ComUE, 12 Rue Pierre Semard, \\ 38000 Grenoble, France; anne-lorene.vernay@grenoble-em.com \\ * Correspondence: saskia.vanbroekhoven@pbl.nl; Tel.: +316-2137-5774
}

Received: 1 May 2018; Accepted: 2 June 2018; Published: 4 June 2018

\begin{abstract}
Cities pose environmental challenges but also offer possibilities to close material and energy loops and connect multiple societal and ecologic services. This article reviews and brings together the literature on two important new research directions that address urban sustainability by integrating functions or material flows: Circular Urban Metabolism (CUM) and Multifunctional Land Use (MLU). We focus on challenges to MLU and CUM and strategies to facilitate their realization. The review shows that although MLU and CUM differ in what they integrate, they face partly similar integration challenges. In both fields, the collaboration between actors related to particular functions (water safety, recreation), high investment costs and uncertainties about costs and benefits, and legislation that hampers integration are identified as challenges. In both fields, strategies are proposed to facilitate the collaboration between actors. However, other challenges and strategies are specific. Whilst MLU scholars mostly highlight socio-economic aspects of realizing integration, CUM scholars focus more on technical aspects. We find limited cross-fertilization between both fields so far. To stimulate discussion and knowledge exchange, we introduce 'integration of urban functions' as a shared idea for a sustainable urban system. To find further solutions for integration challenges, we propose conceptualizing MLU or CUM initiatives as processes of change, which requires connecting across previously separate 'worlds' and changing previously established monofunctional ways of working.
\end{abstract}

Keywords: multifunctional land use; circular urban metabolism; review; challenges; strategies; urban sustainability

\section{Introduction}

Cities have an important role to play in tackling environmental issues. They are a source of environmental problems and are vulnerable to unpredictable future challenges, such as climate change, food insecurity, and limited resources [1,2]. At the same time, they can be seen as hotspots for solutions and possibilities to close material and energy loops and to connect multiple societal and ecologic services [1-3]. In the past few years, measures that integrate different social, ecological, and economic functions have increasingly raised the interest of scholars and practitioners concerned with urban sustainability [4-7]. Examples are using household waste to produce heat to supply dwellings with district heating and realizing multifunctional urban squares which are used for recreation but can serve as water retention areas in times of high precipitation. By integrating functions, multiple ecological and socio-economical services can be provided simultaneously and synergies can be developed, 
which enables greater overall performance and more sustainable development $[2,6,8-10]$. However, whilst supported by many, their organizational and technological complexity ensures that many of such integrated measures fail to be realized [11,12]. What then are the challenges faced when integrating functions, and what are strategies that can help facilitate these important new directions to bring about urban sustainability?

In this paper, we review and bring together existing literature on the development of integration of functions, focusing on two integrative approaches; namely, multifunctional land use (MLU) and circular urban metabolism (CUM). Both MLU and CUM are important new directions to bring about urban sustainability through integration of functions. MLU is about integrating various land use functions in a determined area and time period $[6,13]$. CUM is about creating local cycles of material and energy in order to decrease the environmental burden of existing urban areas [14,15]. These are not the only integrative approaches; they complement other concepts that address the idea of mixing urban functions and flows, such as mixed land use, compact city, and low carbon city. MLU and CUM are, however, specifically interesting to focus on if we want to study the specificities and challenges of integrating functions. Firstly, both approaches have as their core ambition the integration of (physical) functions. In contrast, concepts such as compact city and low carbon city are broader; they, respectively, are about designing cities to have high density, and-besides integrating material flows- the promotion of soft modes of transportation and efficient building. Moreover, MLU and CUM do not just aim to integrate but also aim to address urban sustainability by creating synergies between previously separated functions $[6,16,17]$. Secondly, despite these similarities, MLU and CUM have so far been studied by separate research communities. Research on both developed independently to one another and there has been very little cross-fertilization. Whilst research has been done on the barriers faced by both MLU and CUM and to develop tools or strategies to overcome them, at present an overview of integration challenges and strategies that facilitate integration spanning across both research communities is missing. MLU and CUM share many similarities and scholars can build on each other's work. For example, both concepts connect previously separated socio-technical worlds, involving besides synergies also a variety of social and technical coordination challenges. It requires coordinated activities between actors (individuals and organizations), related to particular functions, with possibly conflicting perceptions and interests, who have to manage a great deal of legal, economic, and technical requirements and objectives.

The literature review was conducted with two objectives in mind. The first objective is to provide an overview of the academic research efforts into MLU and CUM and bring both fields together. We want to know to what extent and what types of integrations are studied in MLU and CUM, how, and with what perspectives. The second objective is to bring together insights on the challenges to and strategies for integrating functions and see to what extent they concur or differ in order to develop a more generalized understanding of underlying factors and facilitate knowledge exchange.

\section{Materials and Methods}

The literature was first searched using the scientific databases of Scopus and Web of Science. For MLU, we used as search tags "multifunctional land use" and "multifunctional landscapes" combined with urban/city/cities. This resulted in a total of 161 papers. For CUM, a search for "circular urban metabolism" only resulted in two papers. Even though the concept is widely used by practitioners and institutional bodies (see for instance [18-22]) when talking about best practices in sustainable urban development, scholars prefer using more specific concepts, such as sustainable implant, zero-waste, self-reliant city, urban harvest, cyclic design, city as ecosystem, circular urban systems, or territorial ecology. These reflect the specific aims of the paper which may be to close cycles locally, harvest local resources, decrease the dependency on an external resource, or minimize waste. To broaden the results, we searched for "urban metabolism" combined with other terms that embody the notion of circularity: "industrial ecology", "closing cycles/loops", "closed cycles/loops", and "zero waste", leading to 66 additional papers. We further completed the literature search using 
Google Scholar with similar search tags. Due to a high number of results for MLU, we here combined the search tags with words similar to "challenge" and "strategy" to aid finding relevant studies. We assessed those studies that appeared in the first 10 pages of the results.

To refine the search results, we scanned the titles and abstracts of the articles using the following criteria: Firstly, we selected papers that matched with our focus on the urban context. We excluded studies that focus on non-urban (e.g., agricultural, rural) applications. Studies analyzing CUM or MLU conceptually without making a distinction between urban or rural applications were included. Secondly, to provide insight for our research question we required that the studies addressed drivers, challenges, and/or strategies for bringing about CUM and MLU. We omitted those that only mention MLU or CUM (e.g., as a possible strategy) but do not analyse it conceptually or empirically as well as studies that only discuss impacts of measures (e.g., impacts on sustainability). Thirdly, only peerreviewed articles and books or book chapters were included. Fourthly, the literature search on CUM resulted in multiple articles that study "urban metabolism" but that do not specify creating circular urban metabolism or closing cycles. However, some of these papers do position analyzing urban metabolism as a strategy for optimizing a city's metabolism, and are referred to as a strategy for CUM by other studies. We included these studies if they were cited at least twice by articles that met all our selection criteria.

The selection was further completed by checking reference lists from selected articles for further useful references and checking articles that cite the selected articles. The above approach resulted in 30 studies on MLU and 23 on CUM being selected (see Appendix A).

\section{Introducing MLU and CUM}

\subsection{Introducing Multifunctional Land Use}

Multifunctional land use refers to "the implementation of more functions in a determined place in a determined period of time" [23]. Whilst multifunctional use of urban space is perhaps as old as cities themselves, functions such as housing, work, infrastructure, and nature became separated in space (e.g., housing and working) and time (working hours) in many European and North-American cities with the coming of industrialization-for health or economic reasons-and later under the influence of functionalism and zoning [24,25]. Jane Jacobs [26] first criticized this monofunctional approach, arguing that compact mixed urban areas are more economically viable, safer, socially stable, and culturally and aesthetically interesting than monofunctional suburbs. In the past few decades, this idea has reappeared in planning literature, now adding that by mixing functions less space is needed and that it will require less traffic [9]. In the planning literature, it is associated with high density and has inspired various concepts, including compact city (designing cities to have high density), smart growth (concentrating growth in high density, walkable, bicycle-friendly areas), and mixed land use (combining uses, e.g., residential, commercial, and working). More recently, the concept of MLU has arisen in Dutch spatial planning especially. There is some discussion on the question of what is (not) MLU. MLU is generally understood to differ from other mixed and dense land use concepts by a focus on creating synergies between functions and promotion of a sustainable form of land use more than sharing physical space $[6,17,24]$. Moreover, scholars have argued that whether an area is multifunctional depends on how the area and time frame is defined. Rodenburg and Nijkamp [9] propose that the concept is best understood as relative-not-binary and defining a degree of multifunctionality rather than demarcating between mono- and multifunctional land use: "a land use pattern is said to become more multifunctional when, in the area considered, the number of functions, the degree of interweaving, or the spatial heterogeneity increases".

Multifunctionality has also gained attention in landscape ecology with the notion of multifunctional landscapes (the promotion of multiple economic, ecological, and social land use functions on the same land simultaneously and to mutual benefit [6]) and in agro-economics (describing agricultural diversification). The notion of multifunctional landscapes has been mostly applied to 
agricultural systems, but has more recently been also applied to the urban (eco)system, e.g., green-blue infrastructures and urban agriculture. For readability, we refer to both concepts as MLU.

MLU is now seen as a solution to deal with multiple challenges cities face and develop sustainable measures that-by 'stacking' functions-simultaneously support environmental health, economic vitality, and other social needs and exploit synergies between functions $[2,6,9]$. The idea is to combine functions that together provide something more and are more sustainable. For example, community greening projects could support higher biodiversity as well as have social benefits by engaging local residents and enabling community development. Another example is green-blue urban infrastructures where functions, such as waterfronts and flood management, climate adaptation, green space, community development, economic functions, and recreation, are combined. This is, for example, applied in the Dakpark Rotterdam in The Netherlands where a large public park is built on the roof of a commercial center and over a water defense structure, providing green space, community development, and employment in a deprived and dense urban area $[27,28]$. Another example is the idea of the East London Green Grid in the U.K. to develop green-blue structures that provide water buffers, develop more green areas and connect areas of urban vegetation, mitigate urban heat island effects, and enhance air quality in order to provide ecological benefits as well as improving health and social wellbeing [29]. Although MLU is hence about creating win-win solutions, combining functions can also lead to (unexpected) adverse effects. It often requires making some compromises towards achieving goals that one might have when thinking from the perspective of only one function, and not all functions combine well with each other. In the Dakpark, for example, realizing other functions very close to the water defense structure led to many discussions on how water safety could be guaranteed (see e.g., [28]).

\subsection{Introducing Circular Urban Metabolism}

Circular urban metabolism (CUM) refers to a situation where cities' outputs are used as inputs in the production system (see also [15]). In this context, the term urban metabolism refers to the "sum total of the technical and socioeconomic processes that occur in cities, resulting in growth, production of energy, and elimination of waste" [30]. It was coined by the American engineer Abel Wolman [31] (1965) in his pioneering book "The metabolism of cities". Responding to growing concerns regarding air and water pollution, he quantified the in and out flows of energy, water, and material of a hypothetical city and showed the connection between goods consumption and waste generation [32]. Building upon his work, Girardet [14] highlighted the fundamental differences between linear and circular urban metabolism. A linear urban metabolism refers to situations where no links are made between inputs of resources and outputs of waste. Many scholars argue that the environmental burden of cities comes from the fact that they have a linear metabolism $[3,33,34]$. Cities did not always function in that way. They have long been considered as places where resources could be harvested for industrial and agricultural processes. This changed by the end of the 19th century, when the notion of urban waste and wastewater emerged and centralized solutions were developed to dispose of this waste [35].

The central idea of CUM is that by closing loops urban areas can be developed with less environmental impact and more in balance with the natural ecosystem upon which they depend as the use of materials and production of waste is reduced [36]. CUM conceptualizes the city itself as an ecosystem where the cyclical nature of natural ecosystems should be reproduced [10]. This conceptualization closely relates to the research field of Industrial Ecology, where scientists draw inspiration from ecosystems for how to create more sustainable industrial systems and transform industrial processes from linear to closed-loop systems where wastes can become inputs for new processes [37]. Recently, CUM has raised much interest in this research community [4]. The idea of CUM is also found in related concepts, such as eco-city, low-carbon city, or smart city. However, CUM is something more specific than these adjacent fields and concepts; it concerns initiatives that integrate material and energy inputs and outputs that belong to different user functions (e.g., heating, food consumption or production, cooking, cleaning) to create local cycles of material and energy 
in order to decrease the environmental burden of existing urban areas. In these related concepts, CUM is one of the solutions to decrease the environmental burden of cities along with non-integrative solutions, such as the promotion of soft means of transportation, of energy efficient buildings, or the use of information and communication technology to optimize urban infrastructure. An example of CUM is using organic waste to produce biogas and compost through anaerobic digestion, which has, for example, been applied in Lille Metropole in order to integrate waste, transport, and energy systems [38]. Another application is Hammarby Sjöstad, a district in Stockhom, where CUM was used as the guiding principle in its development. Here, various forms of municipal waste (sewage, organic waste, municipal solid waste) are used as an energy source to produce district heating, district cooling, and biogas for cooking and for transportation [39]. Similarly, the Geneva Region uses CUM as a guiding principle for regional development. They, for instance, initiated a project aiming at reusing or recycling demolition waste in order to minimize the use of natural gravel [40]. Similar to MLU, although we here point out the advantages of closing loops, it may also lead to (unexpected) adverse effects.

\subsection{General Observations on the Literature}

Most studies on CUM and MLU have been published in environment- and planning-oriented journals (see Appendix A). The reviewed articles on MLU were mostly published in journals related to landscape ecology and planning whilst the articles on CUM cluster around the themes of urban technology, urban planning, and industrial ecology. Surprising is that most publications are relatively recent (mainly since 2004), even though both approaches have been around for a few decades. There is especially an increase in the number of publications about CUM since 2007, and since 2009 in publications on multifunctionality in the urban system in landscape-ecology-related journals.

Many of the reviewed articles concern cases in The Netherlands followed by the U.K. In both countries, MLU and CUM have gained much interest from policymakers (see [6,41]). More generally, most empirical studies take place in North America and Western Europe.

CUM and MLU are both well-recognized as important innovative directions to bring about urban sustainability. The motives for and expected benefits of both are rather similar. Environmental considerations are a main motive. CUM is seen as a way to minimize cities' ecological footprint [14]. MLU is seen as a solution to develop a more sustainable form of land use by combining ecologic and socio-economic aims. Furthermore, MLU and CUM are seen as a way to make cities more self-reliant [14,42], e.g., enabling urban food security [43-45] or improving water management [46,47], thereby building their capacity to adapt to challenges such as climate change and resource scarcity (e.g., $[2,36,48,49]$. Both CUM and MLU are also presented as ways to improve spatial planning (e.g., $[16,23]$ ) and livability in urban areas $[26,45,50]$. For MLU, an important driver is pressure on space $[9,23,48]$. Economic considerations also play a role. For CUM, scholars mention creating jobs and boosting the local economy [21,51]. For MLU, scholars argue that multifunctionality can enable the realization of projects that in isolation cannot be achieved due to insufficient resources by coupling public projects costing money (e.g., redevelopment of obsolete industrial sites or neighborhoods, green structures) with private projects promising benefits (e.g., housing, offices) [52,53]. Moreover, broader public support may be built when multiple stakeholders related to particular functions share support for a MLU development [48,54]. Finally, CUM and MLU are seen as ways to reconnect communities with their surrounding environment $[6,54,55]$, e.g., reconnecting food production and consumption with restaurants using products from their own rooftop farm [45].

Regarding MLU, noticeable is that there is little referencing across studies from the planning and landscape ecology fields. Moreover, scholars working in both fields use different (though clearly related) concepts (see Appendix A column 6). 


\subsection{Types of Integration Studied}

The reviewed articles show a variety of multifunctional and circular strategies designed in different forms and applied at different scales. MLU and CUM are studied in different fields, focus on different things they integrate and scales on which to do so, and involve different lines of thought.

MLU aims to integrate land use functions onto the same space, and focusses on physical space. Two categories can be distinguished: Firstly, some studies focus on the integration of socio-economic functions, e.g., combining shops, transport infrastructure, housing, and amenities. Secondly, many studies focus on integrating ecological and socio-cultural objectives in urban areas, often referring to the provision of multiple ecosystem services. Here, strategies include multifunctional green infrastructures (e.g., combining green areas with recreation and community development $[2,28,56]$, combining urban water management with ecological and socio-cultural functions $[46,47,57]$, and multiple ecosystem services provided by urban forestry [44]. Another strategy is multifunctional urban agriculture, e.g., food production on buildings, such as rooftop farms, rooftop greenhouses, and indoor farming $[43,45]$. More conceptually, authors discuss the integration of human and natural elements of the landscape [54,58].

Rather than land uses, CUM is about linking human activity and connecting materials and energy flows that belong to different user functions. Most studies focus on connecting inputs and outputs between the systems of energy, waste management, and sanitation, e.g., waste recycling, producing biogas from black water (water from the toilet), and producing energy from solid and organic waste [51,55,59-61]. Other types of integrations studied are connecting (urban) agriculture with other systems, e.g., fertilizing urban forests using nutrients from local wastewater [55,60,62], recycling construction and demolition waste [21,63], and connecting in- and outflows from industrial and recreational activities, e.g., using residual heat from industrial processes to heat swimming pools and dwellings [59,62]. CUM is found at two scales: the scale of the building, where input and output to the building is considered, and at the scale of a city, where material and energy flows within cities might be connected (e.g., heat networks).

Despite obvious differences regarding what MLU and CUM are trying to integrate, signs of conceptual connections are being made. Some recent publications discuss integrating urban functions as well as the material and energy flows of these functions. Thomaier et al. [45] discuss how sustainability benefits of urban agriculture can be further enhanced by recycling resources such as water, energy, and organic waste, e.g., improving the energy efficiency of buildings with roof top or vertical farms (like green roofs), using excess heat of rooftop greenhouses for heating, and using organic waste for composting. Agudelo Vera et al. [59] and Leduc and van Kann [62] consider the different functions urban areas have in their studies on integrating material and energy flows. They identify urban functions of an area (recreation, transportation, district heating, etc.) and analyze the role each function plays in the urban metabolism (how much resources they require and wastes they produce) in order to determine how flows can be integrated. Moreover, MLU and CUM share that they are both important innovative directions to bring about urban sustainability through integrating and face similar integration challenges. The next section delves into the challenges and strategies in both fields.

\section{Challenges and Strategies}

The above shows the opportunities to use CUM and MLU as a strategy for urban sustainability. Whilst successful examples exist, the complexity of integrating functions ensures that many other initiatives perish. Reviewing the literature reveals a number of challenges covering technical, economic, organizational, institutional, and social dimensions. To our surprise, despite the fact that challenges are often mentioned in the literature, we only found a limited number of studies that empirically analyze challenges. The degree of empirical evidence and the depth in which challenges are studied varies substantially across studies. In some studies, challenges are explicitly and exhaustively analyzed and underpinned by empirical (case) studies, whilst in others they are not the focus of the study or not underpinned by empirical cases but rather seem to come from authors' experiences over time with 
CUM and MLU. In contrast, strategies often do result from empirical studies. In Table 1, we show how challenges and strategies to MLU and CUM were derived in the reviewed studies. Below, we first discuss challenges and strategies for MLU and CUM separately. In Section 4.5, we reflect on to what extent similar conclusions are found in both fields.

Table 1. Challenges and strategies for integrating function in multifunctional land use (MLU) and circular urban metabolism (CUM) and how they are derived by reviewed studies: derived empirically (e) or deduced from theory or postulated (t).

\begin{tabular}{|c|c|c|}
\hline & Multifunctional Land Use & Circular Urban Metabolism \\
\hline Challenges & $\begin{array}{l}\text { Collaboration between actors across organizational, } \\
\text { sectoral, and disciplinary boundaries } \\
\text { (a) Different epistemological backgrounds (t), } \\
\text { differing perceptions of problems } \\
\text { and solutions (e) } \\
\text { (b) Fragmented institutional settings (e) } \\
\text { (c) Conflicting interests }(\mathrm{t}) \text {, competition, negative } \\
\text { externalities between functions ( } \mathrm{t} \text { ) } \\
\text { (d) Not including all stakeholders, } \\
\text { power differences (e) } \\
\text { Economic: Costs, uncertainty of costs and benefits (e) } \\
\text { Legislation does not match integrated initiatives }(\mathrm{t}) \\
\text { Lack of knowledge, risks, uncertainty (e) }\end{array}$ & $\begin{array}{l}\text { Collaboration across sectors and across city and } \\
\text { legal-jurisdictional boundaries, between actors with } \\
\text { different backgrounds }(\mathrm{t}) \text {; Differing perceptions of } \\
\text { problems and solutions }(\mathrm{e}) \\
\text { Need to change user behavior }(\mathrm{e}) \\
\text { Legislation does not match integrated initiatives }(\mathrm{t}) \\
\text { Economic: Costly, requires long term investments } \\
\text { and high political commitment }(\mathrm{t}) \\
\text { Competing claims for resources }(\mathrm{t}) \\
\text { Different optimal scale for different resources }(\mathrm{t}) \\
\text { Separate rather than holistic design } \\
\text { of infrastructures }(\mathrm{t})\end{array}$ \\
\hline Strategies & $\begin{array}{l}\text { Participatory planning process, including all } \\
\text { stakeholders (e) } \\
\text { Facilitate interaction by joined developing of } \\
\text { knowledge and goals; a shared vision; and providing } \\
\text { regular feedback (e). E.g., using workshops, } \\
\text { scenarios, visualization techniques }(\mathrm{t}) \\
\text { Transdisciplinary approach; shared } \\
\text { conceptualization }(\mathrm{t}) \\
\text { Adaptive/learning approach: testing and monitoring } \\
\text { new ideas, enable learning between stakeholders }(\mathrm{t}) \\
\text { Enable informed decision-making by making } \\
\text { benefits and costs more clear, develop integrated } \\
\text { assessment tools }(\mathrm{e})\end{array}$ & $\begin{array}{l}\text { Analyze urban metabolisms to a) identify and } \\
\text { geographically locate opportunities for integration } \\
\text { (e); b) design policies (e); and c) trigger discussion } \\
\text { and exchange between disciplines ( } \mathrm{t} \text { ) } \\
\text { Involve utilities to coproduce solutions and } \\
\text { recognize their mutual dependence (e) } \\
\text { Develop education programs to train practitioners to } \\
\text { think in holistic terms (e) }\end{array}$ \\
\hline
\end{tabular}

\subsection{Challenges to Multifunctional Land Use}

To start with, difficulties to bring about MLU stem from fragmentation of the institutional system: with tasks, responsibilities, and authorities sharply demarcated between government systems $[5,41,53]$. As a result, organizations approach spatial development from a monofunctional perspective [53]. Van Ark [41] describes how the Dutch institutional context, where policy and spatial claims are developed from policy sectors (nature, housing, working, etc.), leads to different policy practices that hinder integrated planning. Moreover, organizations link policies and plans to their territorial boundaries (e.g., municipality or province) complicating collaboration (ibid). MLU initiatives by definition cut across such established divisions of policy sectors and involve a large variety of public and private actors. For instance, developing green-blue infrastructures involves actors such as project initiators, urban planners, water managers, engineering specialists, investors, city administration, neighbors, and scientists. Van Broekhoven et al. [28] conceptualize the process to develop an MLU initiative as one of fragmentation and integration; realizing multifunctionality requires actors to transcend well-established boundaries; e.g., of sectors, organizations, and physical functions, whilst at the same time effective integration is complicated by the need and/or desire to maintain boundaries, e.g., to ensure fulfillment of functional tasks or maintain hegemony in the wider political-administrative environment.

This leads to various coordination challenges between actors from different backgrounds. Where modernist planning sought to eliminate potential conflicts by separating land uses, MLU in essence creates new ones by incorporating (or even celebrating) this inherent complexity 
of urban development [5]. Although the idea is often that MLU is just about win-win situations, realizing synergies often also requires making compromises towards achieving one's own goals $[64,65]$. Moreover, challenges stem from institutional norms and routines shaping actors' behavior, which may not match with each other and the integrative ambition [5], such as existing rules and regulations made for particular functions $[9,23,45,66]$. For example, zoning and building regulations may not match with urban farming, and environmental legislation can form problems for combining housing and recreation with infrastructure [23,45]. Furthermore, different perceptions of problems and solutions complicate effective communication [66], e.g., due to differing epistemological backgrounds $[2,46,48,67]$. Naveh [54] talks about "diseases of specialized deafness" to highlight people's tendency to ignore things outside their own expertise. Diverging academic traditions, differences in what constitutes meritable work, training programs not encouraging interdisciplinarity, and a lack of a common approach to bridge between disciplines all complicate collaboration $[46,67,68]$. The way the interaction between actors is organized also affects the success of the process. Majoor [5] finds that an 'introvert' governance setting, where not all stakeholders actively participate in thinking about the development of an MLU project, leads to difficulties. Unequal power relations can also complicate interaction [64].

Another cause of challenges concerns the innovative (technical) nature of many multifunctional strategies: a lack of knowledge regarding design and technical possibilities [23,43], an unknown nature and size of risks, and uncertainty of the long term effects of integrating functions [23]. Moreover, technologies may be known but not used together yet, and new technologies may not be easily accepted [43]. Also, the lack of a reference project to fall back on, or of practical experience, makes MLU challenging [45,66], and may lead to risk-avoiding behavior by potential participants [23]. Furthermore, when ecological functions are involved, this may lead to uncertainties on the effects and impacts [6].

High development costs are another challenge identified in studies on combining amenities $[9,23,69,70]$ as well as multifunctional farming [43,45]. Positive synergy benefits might cover a higher development cost; however, Rodenburg [69] and Eijgenraam and Ossokina [71] find that for a specific MLU project small positive synergy benefits exist in terms of willingness to pay, but this may not cover higher development costs. Moreover, costs and benefits for different actors are uncertain as often different sources of financing are involved [23], and many benefits are unpriced, hard to quantify, or both, e.g., productivity improvements, agglomeration advantages, economies of scale $[17,69,70]$, or ecosystem services [11]. Moreover, the time-consuming negotiation process may deter commercial investors [70]. Figure 1 shows the challenges that we have identified above and the number of studies that have found them problematic to MLU.

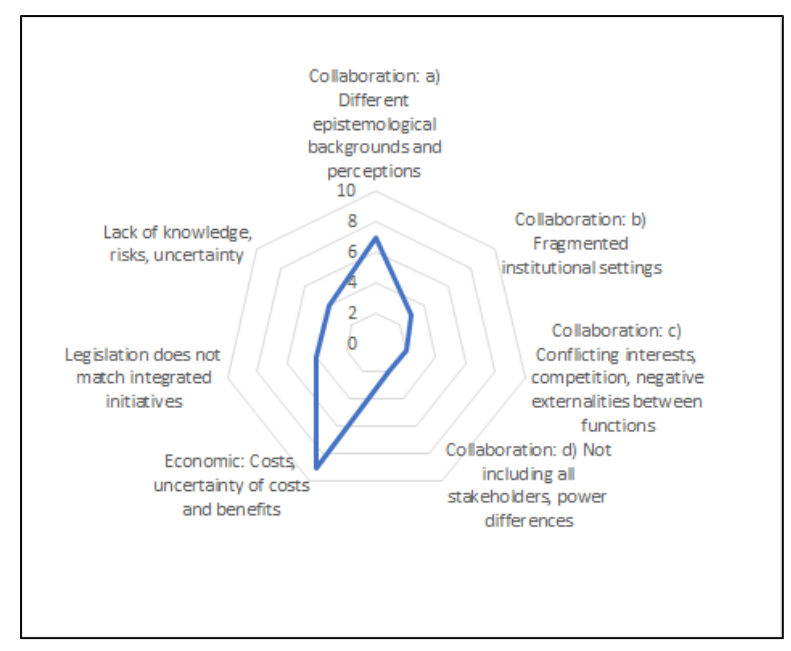

Figure 1. Challenges to MLU and the number of studies identifying them as problematic. 


\subsection{Strategies for Multifunctional Land Use}

To facilitate actors' interaction, several studies state that a participatory approach involving all relevant stakeholders is crucial $[2,5,53,64]$. Some specifically stress the importance of community involvement, to, e.g., encourage commitment from residents, increase residents' satisfaction with results, and enable using local knowledge $[2,16]$. Strategies proposed to manage the interaction include: joint development of knowledge, ideas, and goals, e.g., by creating a setting where stakeholders (both proponents and critics) can discuss the meaning of a place and the pros and cons of MLU [5]; developing a shared conviction or vision on MLU [5,53]; regular feedback between experts and local stakeholders and consistency in the approach taken [53]; a design workshop where 'experts' help stakeholders with their vision [2]; scenarios to explore opportunities and alternatives (ibid); and visualization techniques to understand landscape conditions and evaluate alternatives (ibid). Realizing integration, however, does not mean doing everything together. Van Broekhoven et al. [28] find that boundary-spanning strategies (e.g., jointly developing plans, working in joint project groups) facilitate interaction, but that it can also help to (jointly) reconstruct boundaries in the MLU project, e.g., dividing tasks and responsibilities, which can create a sense of order and clarity in terms of responsibility and accountability and hence enable implementation.

Furthermore, a transdisciplinary approach towards managing and analyzing MLU-i.e., bringing together scientific disciplinary expertise as well as practitioners-can provide a more holistic analysis of interacting factors $[54,57,68]$ and enable a better understanding of the impacts of an intervention for different stakeholders as well as the multiple benefits thereof [46]. Above, we discussed challenges for a transdisciplinary approach. To bridge the gap between disciplines, several studies propose (in addition to the strategies facilitating interaction above) common conceptualizations or design frameworks that can serve as common ground [46,67,68].

To deal with uncertainties and adapt to emerging knowledge, information, and system dynamics, recent papers highlight a learning and adaptive approach. Some propose conceiving cities as 'living laboratories' where learning from small failures and successes can enable testing and monitoring new ideas to improve future design and small scale 'safe to fail' experiments by early adopters can help to diffuse technologies [2,48]. O'Farrell and Anderson [11] suggest forming transdisciplinary 'learning organizations'; i.e., temporary groups that share and develop knowledge, resources, and ideas towards a common goal, are managed adaptively to meet this goal, and deal with natural and social system dynamics.

There have been various efforts to develop assessment tools to enable informed decision-making, such as valuation of land use functions and economic analysis of integrating functions [17,69-71]. O'Farrel and Anderson [11] provide a review of tools to analyze landscapes and their functioning. Scholars highlight that, to develop a holistic analysis, integrated assessment in planning and decision-making is essential, i.e., including ecological, socio-cultural, and economic values and perceptions of the area, and that tools for this need to be developed [11,17,70]. Paracchini et al. [72] provide a tool for the integrated assessment of sustainability of MLU, which can also be used to support discussions amongst stakeholders, e.g., identifying trade-offs between functions and applying weightings. Nardini and Miguez [47] furthermore emphasize that public participation and modelling tools for technical analysis can enhance each other to develop an integrated plan that is shared with both local communities and authorities.

Finally, some functions combine better together than others. Several studies explore and map potential synergies and trade-offs between functions as a strategy to identify where potential for MLU exists $[9,46,56]$.

\subsection{Challenges to Circular Urban Metabolism}

To begin with, important challenges come from the way infrastructure has traditionally been and still is being designed. Firstly, different infrastructures (water, heat, energy) are designed apart from each other by a specialist who may not fully understand how they interact and what the possible 
linkages between them are [73]. In other words, these specialists are not aware of the diversity of metabolic functions that urban infrastructures fulfil [59]. This is further complicated by the fact that prevailing legal-jurisdictional boundaries result in decision-makers having little concern for the external impacts of their decisions [42]. Moreover, Agudelo-Vera et al. [59] argue that different resources are best managed at different scales, e.g., greywater (water from showers and sinks) is best treated at the neighborhood level and construction waste at the regional level. Additionally, cities are very dependent from other geographical areas for the resources they are consuming, and the infrastructure used to a meet a city's demand often reaches far beyond the boundary of the municipality, requiring collaboration between different institutional levels (e.g., municipality, region) [74]. More research is still needed to know what the optimal scale is for closing cycles [49,62].

Moreover, regulatory structures often fail to appropriately support the creation of new metabolic flows or may even prevent their creation [60]. For many years, French regulations for instance did not allow injection of biogas into the natural gas grid [12]. Furthermore, to implement integrated projects often a multitude of permits or exemptions have to be obtained, and failing to obtain one single element can block the realization of the whole system [61].

Another source of challenges is that developing CUM takes large investments. This requires a high and consistent level of commitment from local governments [42,51]. Moreover, CUM applications may involve decentralized solutions, some of which only exist as pilot projects, making it difficult to benefit from economies of scale [61]. Furthermore, different infrastructural development can compete for resources and space [60], e.g., roofs may either be used for photovoltaic panels or as green-roofs [59].

Furthermore, involved actors may have different viewpoints regarding what a CUM should look like [75]. Social coalitions can form around a particular vision of the urban future or, on the contrary, actors can have colliding visions of the future, e.g., with different understandings the problem, and contest each other's position and preferred solution (ibid). Additionally, it is important to understand how power relations between different interest groups shape technological decision-making and design strategies (ibid).

Intersectoral collaboration is often seen as a challenge [51,62,74]. To develop CUM, actors coming from sectors such as electricity and wastewater treatment have to interact. This requires new forms of collaboration between different organizations (e.g., local governments, utilities, construction companies) and stakeholders [51]. This is pointed out by scholars but has not been studied further. Only the study of Ramaswani et al. [74] is an exception. Building on institutional economic literature, authors mention that inter-sectoral collaboration is challenging because actors come from different disciplines and their behavior is shaped by different institutions (rules, social norms, and shared strategies). This supports the observation of Barles [3] that research considering the role of local stakeholders in CUM is limited.

Finally, CUM often involves decentralized types of solutions that require end-users to change their behavior for them to function properly [55]. Greywater treatment systems, for instance, require residents not to use strong cleaning products as this could kill the bacteria needed to clean the water. Changing the behavior of end-users, whose perceptions and habits may not be in line with CUM practices, is challenging [21,51,63]. Figure 2 shows the challenges that we have identified above and the number of studies that have found them problematic to CUM. 


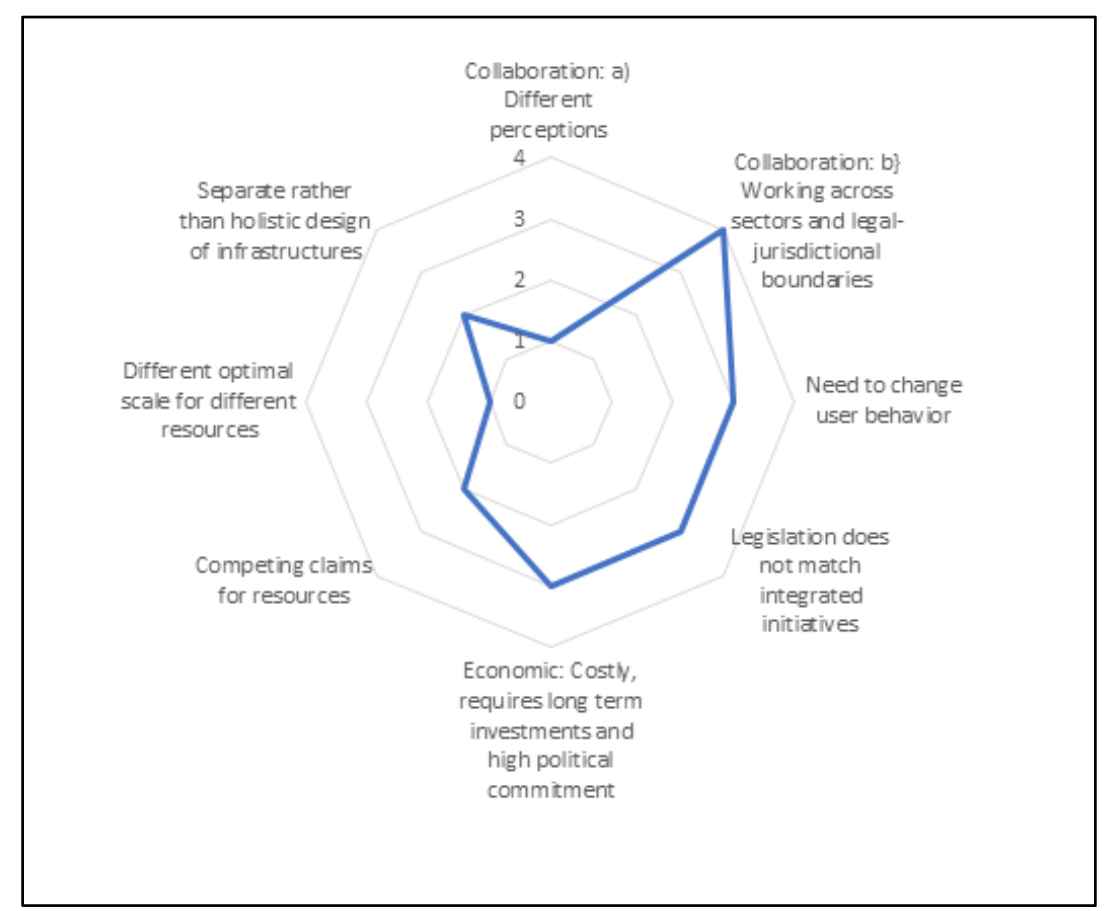

Figure 2. Challenges to CUM and the number of studies identifying them as problematic.

\subsection{Strategies for Circular Urban Metabolism}

Authors often argue that developing CUM requires further analysis of how the metabolism of the city functions, often citing Kennedy et al. [30] who argue that understanding a city's metabolism helps in uncovering the "metabolic processes that threaten the sustainability of cities". Scholars also refer to Newman's [50] argument that this data can then help to identify the activities between which circular flows could be created, and to Barles [35] who shows that it allows for allocating resources to those activities that can deliver the most benefits. Analyses of a city's metabolism can also be used to support policy design $[3,30,49,60,63,76]$. Recent papers highlight that in order to design policies that foster CUM, it is necessary to go a step further than assessing the type and size of material and energy flows, and to (1) understand how metabolic flows are influenced by urban forms, drivers, and lifestyle $[3,50,77]$ - for example a denser city requires less energy for transportation but may face difficulties in sorting waste due to a lack of space-and (2) to understand how social, health, and economic factors influence consumption behavior and thereby metabolic flows [1,78]. However, urban metabolism studies are not easy to accomplish, and it is often difficult to access data at the municipal scale [30,49]. To overcome this, Voskamp et al. [79] propose a tool (SIRUP) that helps (1) identify the kind of data required by urban planners to develop resource-conscious urban planning, (2) assess at which scale is data needed, and (3) identify whether the required data is available.

Some authors argue for an area-specific approach to facilitate CUM. Agudelo-Vera et al. [59] and Leduc and van Kann [62] propose the "urban harvest approach". This entails (1) inventorying the spatial functions present in a given area; (2) quantifying their energy demand and output; (3) analyzing the local renewable and residual energy potential; (4) identifying potential linkages and metabolic gaps; and (5) proposing concrete local spatial interventions to improve the efficiency of the urban metabolism. For example, Leduc and van Kann [62] analyzed a Dutch industrial park and identified excess waste heat of $200{ }^{\circ} \mathrm{C}$ which could be valorized if an industrial facility requiring such temperature (e.g., a brewery) was added. Based on this, Leduc and van Kann [62] propose developing policies to attract functions that fill metabolic gaps, and Agudelo-Vera et al. [59] propose policies to increase the diversity of urban functions (recreational, industrial, residential, tertiary). As each function has its own metabolism (with 
specific in- and outflows and a specific consumption cycle, some consuming during the day while others at night), more diversity of functions can enable possibilities to close cycles (see e.g., [80]).

To facilitate interaction between specialists designing different infrastructures and help recognize their mutual dependence, public authorities can encourage utilities (i.e., firms providing public services such as water or electricity) to co-produce integrated solutions [55,61]. For instance, in developing the district Hammarby Sjöstad, the municipality of Stockholm requested utilities to deliver integrated solutions (e.g., to link wastewater treatment with biogas production for cooking) [81]. Furthermore, scholars argue that the education of practitioners should include training to think holistically in developing urban infrastructures [21,74].

Finally, to deal with challenges in end-user behavior in decentralized solutions, Haughton [42] states that end users should be empowered and play a more prominent role in the governance of urban systems.

\subsection{Overview}

This review shows that the challenges for realizing integration in CUM and MLU are partly similar. Table 1 summarizes the challenges faced when attempting to make a transition towards MLU and CUM and the strategies that can help to realize them. We found that the need for collaboration between actors across disciplines, sectors, and government levels is most often identified as a challenge in the reviewed articles. This is especially so for MLU, where almost half the reviewed studies identify this as a challenge. Integration is complicated as it requires collaboration between actors with different epistemological backgrounds who have differing perceptions on problems and solutions. MLU scholars add that interaction challenges find their origin in fragmented and monofunctional institutional settings, which shape actors' actions. For CUM, similar collaboration challenges are found, e.g., across sectors and across city and legal-jurisdictional boundaries and between actors with different perceptions. Surprisingly, however, amongst CUM scholars this has received much less attention than amongst MLU scholars and interaction challenges are hardly studied in depth, with only Ramaswami [75] being an exception. CUM scholars hence can find value in the work of MLU scholars on this challenge.

The review also shows that for both MLU and CUM high investment costs hamper their realization. Several studies by MLU scholars have investigated the costs and benefits in depth. Whilst some studies find that small positive synergy benefits exist, others find high uncertainty about costs and benefits, which may deter investors. The last shared challenge that was found in this review is that scholars in both fields identify that legislation made for monofunctional practices obstructs integrated initiatives. In addition, lack of knowledge was named in both fields, as both approaches are still not often practiced. However, this concerned knowledge on different topics.

CUM scholars in addition identified several challenges that were specific to the development of CUM, such as difficulties in changing user behavior and the common practice to design infrastructures for one function rather than with a more holistic purpose.

Regarding strategies, we found that both MLU and CUM scholars propose strategies aimed at facilitating the collaboration process. Amongst the reviewed MLU studies, this is the main strategy to facilitate MLU. MLU scholars propose and study various tools that can help such a joined process, such as using workshops, scenarios, visualization techniques, integrated assessment methods of, amongst others, costs and benefits, and learning or transdisciplinary approaches. Interestingly, and in line with our findings regarding challenges, whilst MLU scholars mostly highlight the socio-economic aspects of realizing integration, CUM scholars are more focused on technical aspects. CUM scholars in addition to collaboration strategies argue that we need to further analyze and understand the metabolic flows of cities in order to better develop opportunities for and realize CUM and propose ways to do so. 


\section{Conclusions and Discussion}

This review shows that although MLU and CUM differ in what they integrate, they face similar challenges in integration. We found that in both fields the collaboration between actors related to particular functions (water safety, recreation, wastewater treatment) is an important concern. In the reviewed MLU articles this is the main challenge. Remarkably, whilst scholars identify similar collaboration challenges, these have been hardly studied in depth for CUM. The review furthermore shows that both high investment costs and uncertainties about costs and benefits for different actors hamper realization. Moreover, legislation that does not accommodate integrated initiatives was found to hamper both CUM and MLU initiatives.

However, we also found challenges and strategies specific to CUM or MLU. Regarding both challenges and strategies, we find that whilst MLU scholars are mostly focused on socio-economic aspects of realizing integration, CUM scholars are more focused on technical aspects. The strategies to overcome integration challenges that are proposed by MLU scholars are aimed at involving all relevant actors in the planning process and facilitating their collaboration, e.g., by using workshops, scenario's, visualization techniques, integrated assessment methods of amongst others costs and benefits, and learning or transdisciplinary approaches. CUM scholars in addition to collaboration strategies argue that we need to further analyze and understand the metabolic flows of cities in order to better develop opportunities for and realize CUM and propose ways to do so.

To our surprise, we found only a limited number of (case) studies that actually empirically and in-depth studied challenges to MLU and CUM. This hence points at an opportunity for future research to verify and better understand the challenges found in the reviewed studies.

\subsection{Integration of Urban Functions as a Shared Idea for a Sustainable Urban System?}

We found limited signs of cross-fertilization between research on CUM and MLU. Moreover, the review shows that for MLU there is little referencing across studies that use the different though clearly related concepts of multifunctional land use and multifunctional landscapes by scholars mostly coming from, respectively, the planning or landscape ecology field. Likewise, different concepts are used to talk about CUM. Moreover, whilst we have focused on MLU and CUM in this review, they complement other concepts that address the idea of mixing urban functions and flows, such as mixed land use, compact city, and low-carbon city. Reflecting on this diversity regarding MLU, Majoor [5] argues that these concepts should be seen as a provocation to think beyond established monofunctional practices, with the actual meaning, potential, and use of the concept depending on the actors' viewpoint and the local context in which they are developed. The same may be concluded for CUM and currently established linear practices. However, a risk is that academic contributions from different fields of study stay apart because they lack a common language.

With this review, we want to facilitate discussion and knowledge exchange within and between the fields of MLU and CUM as two approaches that propose integration for a sustainable urban system. Based on this review, we propose a possible point of convergence between CUM and MLU: they can both be framed as being about the integration of urban functions. The review moreover indicates some concrete possibilities for knowledge exchange. To start with, CUM scholars can find value in the work of MLU scholars on understanding and facilitating the collaboration between actors from different backgrounds. Moreover, the studies on economic aspects and costs and benefits of MLU developed by scholars from the planning field $[17,69,71]$, and studies on valuation of urban functions by different actors and integrated assessment tools developed by scholars in the landscape ecology field [2,11,72], can benefit both CUM scholars as well as MLU scholars across the planning and the (landscape) ecology research communities. In the field of MLU, more collaboration between scientists and practitioners from urban planning and landscape ecology may help to develop a systems-level view on how a city can develop more sustainably by bringing together knowledge on ecosystem services and principles of ecology with knowledge of planning processes and practice of urban planning and design $[48,68]$. For example, involving scientists and practitioners from both disciplines can help understand the 
multiple benefits and impacts of integrative initiatives for different stakeholders [46]. Moreover, it can help in developing solutions that connect socio-economic functions and ecologic aims. Furthermore, the work by CUM scholars could help frame urban functions not only as being present to fulfil societal and ecological functions or needs, but also as having a role in the metabolism of the city. Besides sharing lessons learned, one could imagine measures integrating land use functions and energy and material flows taking place in the same area to increase sustainability, such as urban farming initiatives involving roof top farming as well as water retention and reuse of organic wastes (see [45]) or neighborhood development where both connecting land use functions as green-blue infrastructures and connecting household material flows is realized.

\subsection{A Process-Oriented Perspective}

Based on our review, to find further solutions for the integration challenges we identified above we propose conceptualizing MLU or CUM initiatives as processes of change, which requires connecting across previously separate 'worlds' and changing previously established monofunctional ways of working. Integrating functions brings together more or less autonomous actors dominantly organized according to the principles of bureaucracy: well-divided into task units specialized and responsible for one function. As discussed by Van Ark [41], many challenges can be attributed to such underlying institutional structures. Whilst to realize integration actors need to work across boundaries of sectors and organizations, studies on inter-sectoral interaction have shown that this is complicated as this involves changing current practices that can be deeply embedded in their structures, histories, and vested interests $[28,82,83]$. We highlight that the different institutional backgrounds and logics of actors related to particular functions require particular attention in future studies. An important future research opportunity is hence the further empirical analysis of the process of change that unfolds when actors initiate an MLU or a CUM initiative, delving into the underlying perspectives, interests, rules, and ways of working of actors that lead to integration challenges, as well as exploring which strategies are helpful at which moments during this process. In doing so, scholars can build upon insights from other fields. Here, we explore two perspectives that could be used and how these can help in dealing with integration challenges.

One perspective is to focus on how actors deal with boundaries in the integrative processes of MLU and CUM. When actors specify integration as their aim, they are confronted with boundaries. 'Integrating' already suggest there are separate entities that need to be brought together. Such boundaries include social boundaries between groups of people, such as spatial planners, water managers, and residents; cognitive boundaries between different perspectives, ways of working, knowledge, and language; and physical boundaries in physical objects and geographical jurisdictions [28]. Actors participating in integrative processes will try to influence the multiple boundaries they experience. They will try to change or bridge boundaries that constrain them, but construct and maintain boundaries that enable them to pursue their goals whilst keeping out external inferences or divide tasks and responsibilities $[28,84]$. Recently, the question of how actors deal with boundaries is rising amongst scholars studying the integrative planning process [28,84-86]. Previous work on boundaries provides insights that can help overcome the integration challenges identified in Table 1. Studies have shown how coordinating across boundaries can be facilitated; e.g., activities of boundary spanners, i.e., people or organizations that act as intermediaries, identify needs and facilitate shared problem perceptions and solutions by communicating and building relations [87], boundary objects, i.e., objects that can serve as means of translation and a basis for coordination between actors [88], or coordination mechanisms (e.g., steering groups) that encourage communication and meaningful exchange and can make group decisions accountable to all [89]. Drawing or defending boundaries can be problematic for cooperation and integration [82,83]. However, studies have also found that drawing boundaries in integrative work can be useful to keep complexity manageable, divide tasks, and create a sense of order or clarity in terms of responsibility and accountability, thereby facilitating realization and making it possible for organizations to fulfil their core (functional) tasks 
into the future. $[28,90]$. To understand how integration is realized in CUM and MLU processes, it is important to address how actors manage boundaries over the course of integrative processes and what strategies to manage boundaries are helpful at different moments during these processes.

Another perspective is to analyze integrating functions as a process of integrating socio-technical systems: we refer to this process as systems integration. It is based on the understanding that technologies are not mere artefacts but are part of a larger whole of inter-related and heterogeneous entities that support and sustain them [91-93]. Science and Technology scholars understand that a socio-technical system is composed of three inter-related elements: technical artefacts, organizations that, in interaction, fulfil a given societal function, and institutions understood as norms, values, and cognitive maps that these actors share with one another [94]. From this perspective, technological change cannot be understood without considering the social context in which these technologies are embedded and with which they co-evolve. Analyzing the integration of functions as a process of systems integration means re-constructing how linkages can be created between previously separated socio-technical systems and understanding how prevailing institutions may enable or constrain change. These linkages may be more or less important and as such various degrees of systems integration exist, each implying different degrees of inter-dependencies between initially separated systems [12]. Previous studies analyzed how actors negotiate their participation in systems integration by co-creating shared rules that allow for securing the highest level of autonomy $[95,96]$. More recently, scholars have shown interest in understanding the dynamics of integrated systems and whether and how they can maintain the capacity to adapt to changing circumstances [97-100]. They especially draw on previous work on intermediaries [71,101] and anchors [102-104], showing how these can also help overcome some of the challenges identified in Table 1. Intermediaries can, for instance, raise awareness about integration possibilities [105], facilitate communication [106], and help raise trust among participants who may be more willing to negotiate the conditions for systems integration $[107,108]$.

Author Contributions: S.v.B. analyzed the literature and wrote the sections on MLU. A.L.V. analyzed the literature and wrote the sections on CUM. S.v.B. and A.L.V. both wrote the remaining sections of the paper, with S.v.B. being the lead author.

Acknowledgments: This research is partly funded by the Dutch Knowledge for Climate Research Program http:/ / www.knowledgeforclimate.nl/

Conflicts of Interest: The authors declare no conflict of interest. 


\section{Appendix A}

Table A1. Reviewed studies.

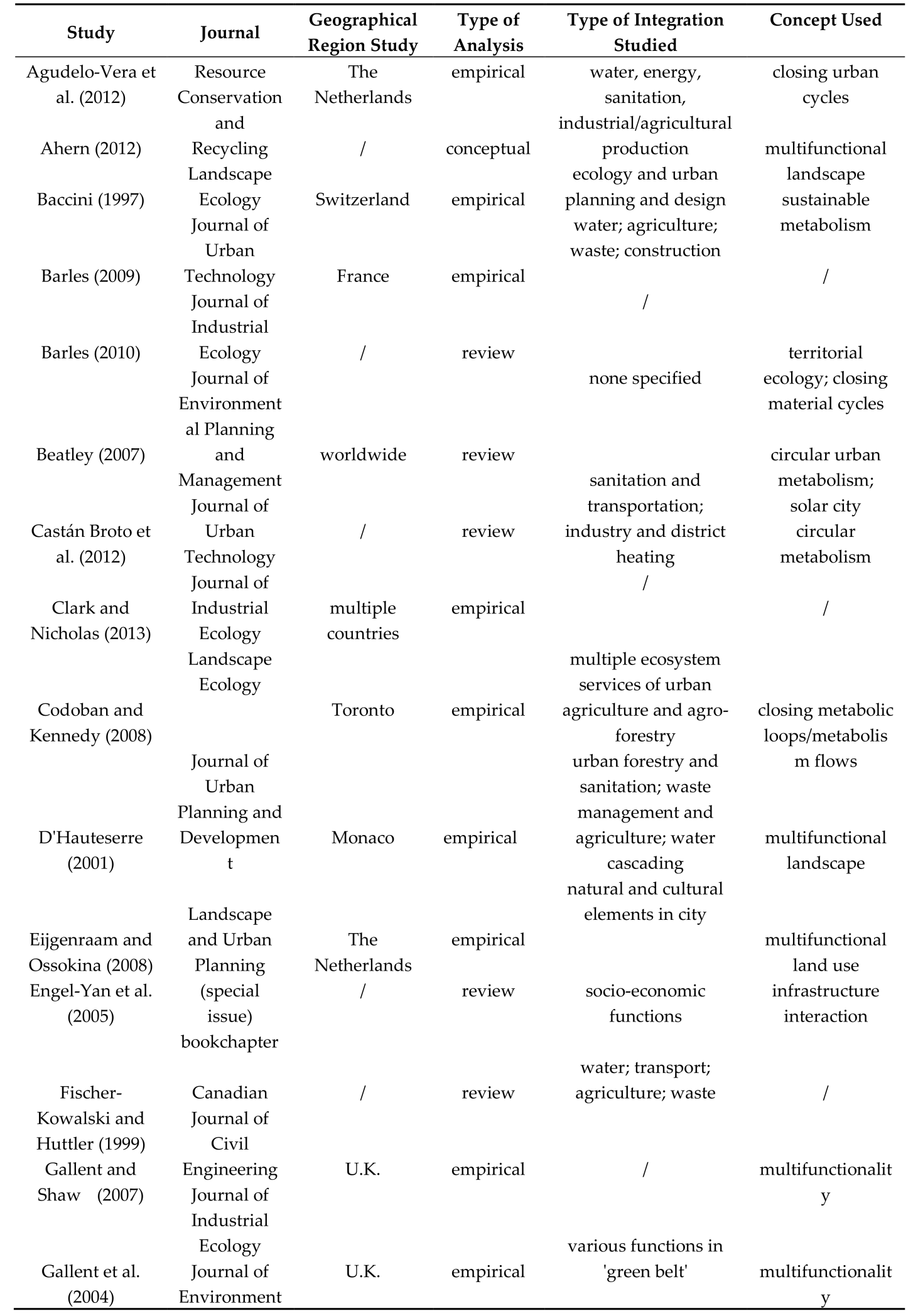




\begin{tabular}{|c|c|c|c|c|c|}
\hline & al Planning & & & & \\
\hline & and & & & cases: (1) Ecological & \\
\hline & Management & & & regeneration, socio- & \\
\hline & Local & & & cultural functions, & \\
\hline & Environment & & & community & \\
\hline Girardet (1992) & $:$ & worldwide & review & development; (2) & circular urban \\
\hline Girardet (2008) & $\begin{array}{c}\text { The } \\
\text { International } \\
\text { Journal of }\end{array}$ & worldwide & review & $\begin{array}{l}\text { Flood management, } \\
\text { ecological } \\
\text { conservation, }\end{array}$ & $\begin{array}{l}\text { metabolism } \\
\text { circular urban } \\
\text { metabolism }\end{array}$ \\
\hline $\begin{array}{c}\text { Guy and } \\
\text { Marvin (2001) }\end{array}$ & $\begin{array}{c}\text { Justice and } \\
\text { Sustainabilit } \\
\text { y }\end{array}$ & U.K. & $\begin{array}{l}\text { conceptual } \\
\text { and } \\
\text { empirical }\end{array}$ & $\begin{array}{l}\text { recreation } \\
\text { none specified }\end{array}$ & $\begin{array}{l}\text { CUM; self-reliant } \\
\text { city }\end{array}$ \\
\hline $\begin{array}{c}\text { Haughton } \\
\text { (1997) }\end{array}$ & Book & I & conceptual & $\begin{array}{l}\text { transport; energy; } \\
\text { waste; water; } \\
\text { agriculture }\end{array}$ & self-reliant, CUM \\
\hline Herzog (2013) & $\begin{array}{l}\text { Impact } \\
\text { Assessment } \\
\text { and Project }\end{array}$ & Brazil & empirical & none specified & $\begin{array}{l}\text { multifunctional } \\
\text { green } \\
\text { infrastructure }\end{array}$ \\
\hline $\begin{array}{c}\text { Kennedy et al. } \\
\text { (2007) }\end{array}$ & $\begin{array}{l}\text { Appraisal } \\
\text { Cities }\end{array}$ & worldwide & review & none specified & / \\
\hline $\begin{array}{c}\text { Kennedy et al. } \\
\text { (2011) }\end{array}$ & $\begin{array}{l}\text { Landscape } \\
\text { and }\end{array}$ & / & review & $\begin{array}{l}\text { ecological functions } \\
\text { and urban } \\
\text { development in green }\end{array}$ & I \\
\hline $\begin{array}{l}\text { Leduc and van } \\
\text { Kann (2013) }\end{array}$ & $\begin{array}{l}\text { Ecological } \\
\text { Engineering } \\
\text { Journal of }\end{array}$ & $\begin{array}{l}\text { The } \\
\text { Netherlands }\end{array}$ & empirical & $\begin{array}{c}\text { infrastructure } \\
/\end{array}$ & $\begin{array}{l}\text { circular urban } \\
\text { metabolism; }\end{array}$ \\
\hline Lehmann (2011) & $\begin{array}{l}\text { Industrial } \\
\text { Ecology }\end{array}$ & worldwide & review & & $\begin{array}{c}\text { urban harvest } \\
\text { zero-waste }\end{array}$ \\
\hline $\begin{array}{c}\text { Lovell and } \\
\text { Johnston (2009) }\end{array}$ & $\begin{array}{l}\text { Environment } \\
\text { al Pollution } \\
\text { Journal of } \\
\text { Cleaner } \\
\text { Production }\end{array}$ & / & $\begin{array}{l}\text { conceptual, } \\
\text { apply } \\
\text { framework } \\
\text { to case }\end{array}$ & $\begin{array}{l}\text { / } \\
\text { residential, industrial, } \\
\text { energy, agriculture; } \\
\text { recreation }\end{array}$ & $\begin{array}{l}\text { multifunctional } \\
\text { landscape }\end{array}$ \\
\hline $\begin{array}{l}\text { Lovell and } \\
\text { Taylor (2013) }\end{array}$ & $\begin{array}{l}\text { Sustainabilit } \\
y\end{array}$ & US & conceptual & $\begin{array}{l}\text { construction sectors; } \\
\text { construction and } \\
\text { demolition waste }\end{array}$ & $\begin{array}{l}\text { multifunctional } \\
\text { landscape }\end{array}$ \\
\hline $\begin{array}{c}\text { Lundy and } \\
\text { Wade (2010) }\end{array}$ & $\begin{array}{l}\text { Frontiers in } \\
\text { Ecology and }\end{array}$ & UK & empirical & $\begin{array}{c}\text { landscape ecology and } \\
\text { urban planning and } \\
\text { design }\end{array}$ & $\begin{array}{l}\text { multifunctional } \\
\text { landscape }\end{array}$ \\
\hline Majoor (2006) & $\begin{array}{l}\text { the } \\
\text { Environment } \\
\text { Landscape } \\
\text { Ecology }\end{array}$ & $\begin{array}{l}\text { The } \\
\text { Netherlands }\end{array}$ & empirical & $\begin{array}{l}\text { ecosystems services } \\
\text { and socio-cultural } \\
\text { objectives in green } \\
\text { infrastructure }\end{array}$ & $\begin{array}{l}\text { multiple land } \\
\text { use }\end{array}$ \\
\hline $\begin{array}{l}\text { Nardini and } \\
\text { Miguez (2016) }\end{array}$ & $\begin{array}{l}\text { Progress in } \\
\text { Physical } \\
\text { Geography }\end{array}$ & Colombia & empirical & $\begin{array}{l}\text { multiple ecosystem } \\
\text { services into water } \\
\text { management }\end{array}$ & $\begin{array}{l}\text { multifunctional } \\
\text { landscapes }\end{array}$ \\
\hline Naveh (2001) & $\begin{array}{l}\text { Journal of } \\
\text { Housing and } \\
\text { the Built }\end{array}$ & / & conceptual & $\begin{array}{l}\text { socio-economic } \\
\text { functions }\end{array}$ & $\begin{array}{l}\text { multifunctional } \\
\text { landscape }\end{array}$ \\
\hline Newman (1999) & $\begin{array}{l}\text { Environment } \\
\text { (special } \\
\text { issue) }\end{array}$ & Australia & empirical & & \\
\hline
\end{tabular}




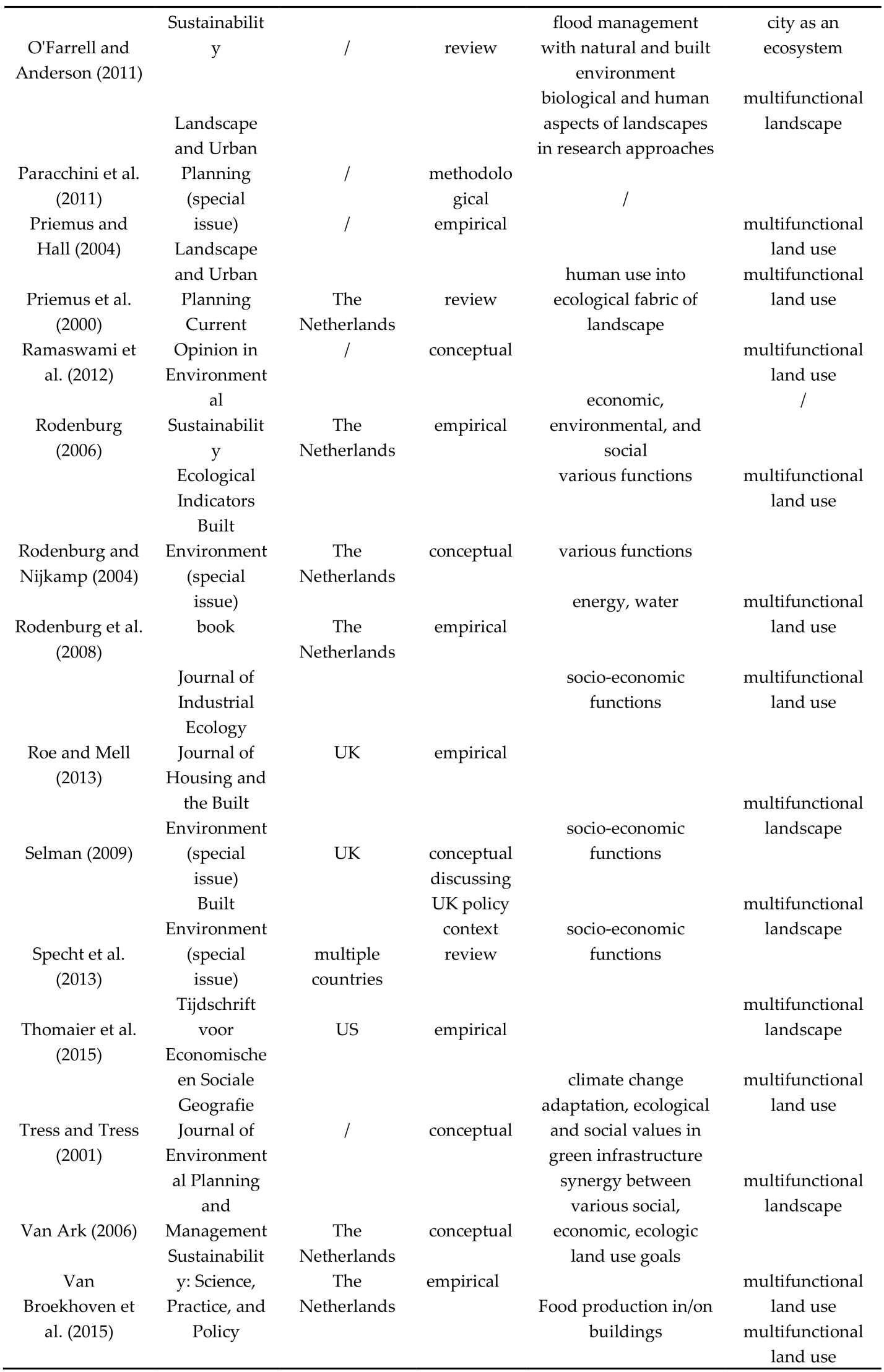




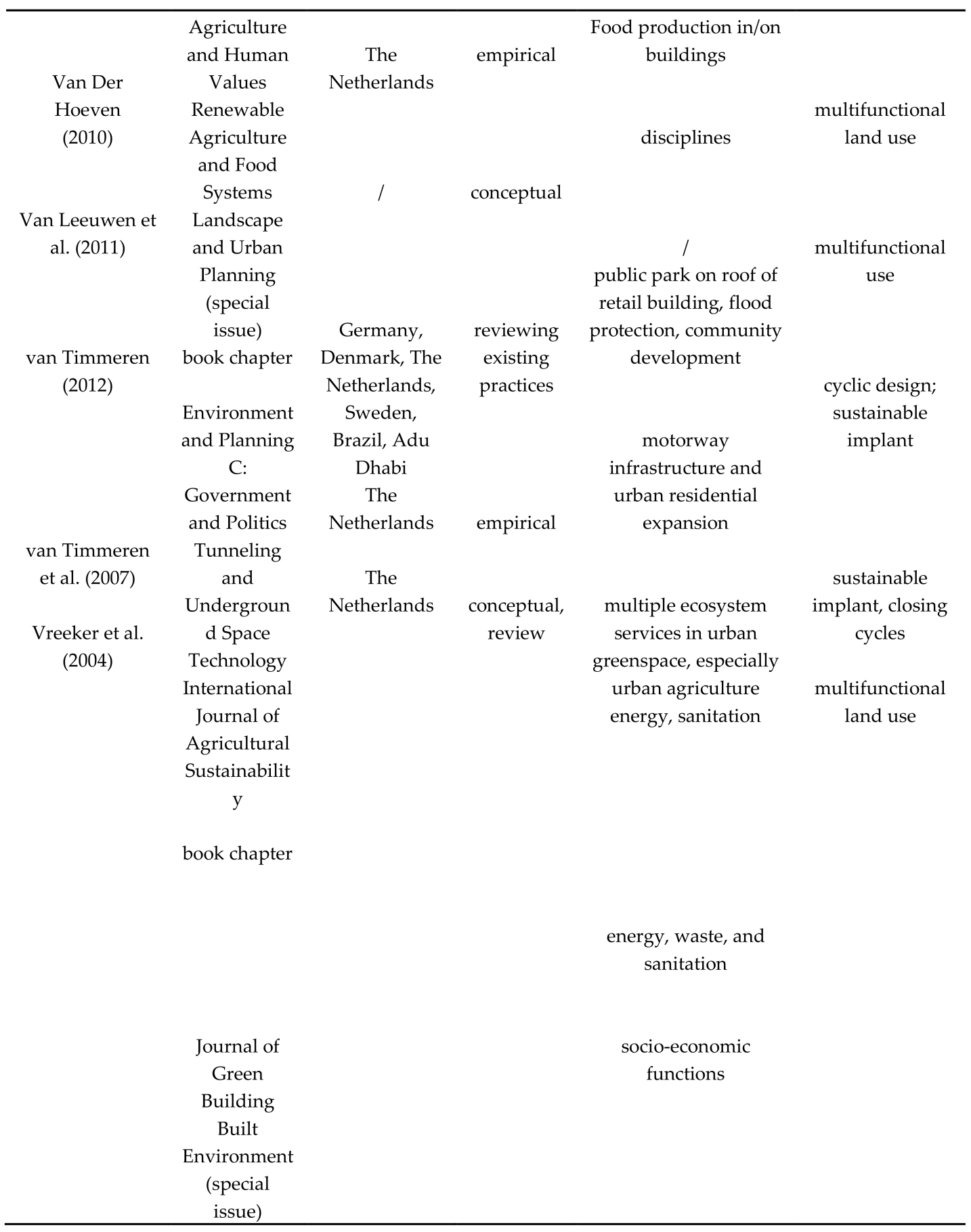

\section{References}

1. Grimm, N.B.; Faeth, S.H.; Golubiewski, N.E.; Redman, C.L.; Wu, J.; Bai, X.; Briggs, J.M. Global Change and the Ecology of Cities. Science 2008, 319, 756-760. [CrossRef] [PubMed]

2. Lovell, S.T.; Taylor, J.R. Supplying urban ecosystem services through multifunctional green infrastructure in the United States. Landsc. Ecol. 2013, 28, 1447-1463. [CrossRef]

3. Barles, S. Society, energy and materials: The contribution of urban metabolism studies to sustainable urban development issues. J. Environ. Plan. Manag. 2010, 53, 439-455. [CrossRef]

4. Broto Castán, V.; Adriana, A.; Elizabeth, R. Interdisciplinary Perspectives on Urban Metabolism. J. Ind. Ecol. 2012, 16, 851-861. [CrossRef] 
5. Majoor, S. Conditions for multiple land use in large-scale urban projects. J. Hous. Built Environ. 2006, 21, 15-32. [CrossRef]

6. Selman, P. Planning for landscape multifunctionality. Sustain. Sci. Pract. Policy 2009, 5, 45-52. [CrossRef]

7. Suzuki, H.; Dastur, A.; Moffatt, S.; Yabuki, N.; Maruyama, H. Eco2 Cities: Ecological Cities as Economic Cities; World Bank Publications: Washington, DC, USA, 2010; ISBN 978-0-8213-8144-1.

8. Vreeker, R. Evaluating effects of multiple land-use projects: A comparison of methods. J. Hous. Built Environ. 2006, 21, 33-50. [CrossRef]

9. Rodenburg, C.A.; Nijkamp, P. Multifunctional land use in the city: A typological overview. Built Environ. 2004, 30, 274-288. [CrossRef]

10. Newman, P.; Jennings, I. Cities as Sustainable Ecosystems: Principles and Practices; Island Press: Washington, DC, USA, 2008; ISBN 978-1-59726-188-3.

11. O'Farrell, P.J.; Anderson, P.M. Sustainable multifunctional landscapes: A review to implementation. Curr. Opin. Environ. Sustain. 2010, 2, 59-65. [CrossRef]

12. Vernay, A.B.H. Circular Urban Systems: Moving Towards Systems Integration. Ph.D. Thesis, Delft University of Technology, Delft, The Netherlands, 2013.

13. Priemus, H. System Innovation in Spatial Development: Current Dutch Approaches. Eur. Plan. Stud. 2007, 15, 992-1006. [CrossRef]

14. Girardet, H. The Gaia Atlas of Cities: New Directions for Sustainable Urban Living; UN-HABITAT: Nairobi, Kenya, 1996; ISBN 978-1-85675-097-4.

15. Rogers, R.G. Cities for a Small Planet; Westview: Boulder, CO, USA, 1997; ISBN 0-8133-3553-1.

16. Gallent, N.; Shaw, D. Spatial planning, area action plans and the rural-urban fringe. J. Environ. Plan. Manag. 2007, 50, 617-638. [CrossRef]

17. Vreeker, R.; Groot, H.L.; Verhoef, E.T. Urban multifunctional land use: Theoretical and empirical insights on economies of scale, scope and diversity. Built Environ. 2004, 30, 289-307. [CrossRef]

18. ACR+ Update-ACR+. Available online: http://www.acrplus.org/index.php/en/publications/2-content/ 335-acr-update (accessed on 13 April 2018).

19. UN-HABITAT. State of the World's Cities 2008/2009—Harmonious Cities; Earthscan: Abingdon, UK, 2008; ISBN 978-92-1-132010-7.

20. Worldwatch Insititute. State of the World 2007: Our Urban Future; W. W. Norton \& Company: New York, NY, USA; London, UK, 2007; ISBN 978-0-393-32923-0.

21. Lehmann, S. Optimizing Urban Material Flows and Waste Streams in Urban Development through Principles of Zero Waste and Sustainable Consumption. Sustainability 2011, 3, 155-183. [CrossRef]

22. Beatley, T. Green Cities of Europe: Global Lessons on Green Urbanism; Island Press/Center for Resource Economics: Washington, DC, USA, 2012; ISBN 978-1-61091-175-7.

23. Priemus, H.; Nijkamp, P.; Dieleman, F.M. Meervoudig Ruimtegebruik; Stimulansen en Belemmeringen; Delft University Press: Delft, The Netherlands, 2000.

24. Louw, E.; Bruinsma, F. From mixed to multiple land use. J. Hous. Built Environ. 2006, 21, 1-13. [CrossRef]

25. Priemus, H.; Rodenburg, C.A.; Nijkamp, P. Multifunctional urban land use: A new phenomenon? A new planning challenge? Built Environ. 2004, 30, 269-273. [CrossRef]

26. Jacobs, J. The Death and Life of Great American Cities; Random House LLC: New York, NY, USA, 1961.

27. Dakpark Rotterdam I Grootste Dakpark van Europa. Available online: http:/ / www.dakparkrotterdam.nl/ (accessed on 13 April 2018).

28. Van Broekhoven, S.; Boons, F.; van Buuren, A.; Teisman, G. Boundaries in action: A framework to analyse boundary actions in multifunctional land-use developments. Environ. Plan. C Gov. Policy 2015, 33, 1005-1023. [CrossRef]

29. London Green Grid I Urban Green-Blue Grids. Available online: http:/ / www.urbangreenbluegrids.com/ projects/london-green-grid/ (accessed on 13 April 2018).

30. Kennedy, C.; Cuddihy, J.; Engel-Yan, J. The Changing Metabolism of Cities. J. Ind. Ecol. 2007, 11, 43-59. [CrossRef]

31. Wolman, A. The metabolism of cities. Sci. Am. 1965, 213, 179-190. [CrossRef] [PubMed]

32. Decker, E.H.; Elliott, S.; Smith, F.A.; Blake, D.R.; Rowland, F.S. Energy and Material Flow through the Urban Ecosystem. Annu. Rev. Energy Environ. 2000, 25, 685-740. [CrossRef]

33. Brunner, P. Reshaping Urban Metabolism. J. Ind. Ecol. 2008, 11, 11-13. [CrossRef] 
34. Dunn, B.C.; Steinemann, A. Industrial Ecology for Sustainable Communities. J. Environ. Plan. Manag. 1998, 41, 661-672. [CrossRef]

35. Barles, S. L'invention des Déchets Urbains: France (1790-1970); Champ Vallon: Seyssel, France, 2005.

36. Girardet, H. Cities People Planet: Urban Development and Climate Change, 2nd ed.; Wiley: Chichester, UK; New York, NY, USA, 2008; ISBN 978-0-470-77270-6.

37. Ehrenfeld, J.R. Industrial ecology: A framework for product and process design. J. Clean. Prod. 1997, 5, 87-95. [CrossRef]

38. Le Centre de Valorisation Organique (CVO). Available online: http:/ / www.lillemetropole.fr/mel/decouverte/ equipements-de-la-mel/dechets-menagers/le-centre-de-valorisation-organi.html (accessed on 13 April 2018).

39. SymbioCity. Hammarby Sjöstad: Three in One. Available online: https://www.symbiocity.org/en/ approach/Cases-undersidor/Hammarby-Sjostad-three-in-one/ (accessed on 13 April 2018).

40. Ecologie industrielle I Environnement. Available online: http://ge.ch/environnement/ecologie-industrielle (accessed on 13 April 2018).

41. Van Ark, R. Meervoudig ruimtegebruik: Dogma of eye-opener. In Meervoudig Ruimtegebruik, Enkelvoudig Recht: De Spanningsvolle Relatie Tussen Recht en Innovatie; Van der Heijden, G.M.A., Slob, A.F.L., Eds.; Eburon: Delft, The Netherlands, 2005.

42. Haughton, G. Developing sustainable urban development models. Cities 1997, 14, 189-195. [CrossRef]

43. Specht, K.; Siebert, R.; Hartmann, I.; Freisinger, U.B.; Sawicka, M.; Werner, A.; Thomaier, S.; Henckel, D.; Walk, H.; Dierich, A. Urban agriculture of the future: An overview of sustainability aspects of food production in and on buildings. Agric. Hum. Values 2014, 31, 33-51. [CrossRef]

44. Clark, K.H.; Nicholas, K.A. Introducing urban food forestry: A multifunctional approach to increase food security and provide ecosystem services. Landsc. Ecol. 2013, 28, 1649-1669. [CrossRef]

45. Thomaier, S.; Specht, K.; Henckel, D.; Dierich, A.; Siebert, R.; Freisinger, U.B.; Sawicka, M. Farming in and on urban buildings: Present practice and specific novelties of Zero-Acreage Farming (ZFarming). Renew. Agric. Food Syst. 2015, 30, 43-54. [CrossRef]

46. Lundy, L.; Wade, R. Integrating sciences to sustain urban ecosystem services. Prog. Phys. Geogr. 2011, 35, 653-669. [CrossRef]

47. Nardini, A.; Gomes Miguez, M. An Integrated Plan to Sustainably Enable the City of Riohacha (Colombia) to Cope with Increasing Urban Flooding, while Improving Its Environmental Setting. Sustainability 2016, 8, 198. [CrossRef]

48. Ahern, J. Urban landscape sustainability and resilience: The promise and challenges of integrating ecology with urban planning and design. Landsc. Ecol. 2013, 28, 1203-1212. [CrossRef]

49. Bai, X. Eight energy and material flow characteristics of urban ecosystems. AMBIO 2016, 45, 819-830. [CrossRef] [PubMed]

50. Newman, P.W.G. Sustainability and cities: Extending the metabolism model. Landsc. Urban Plan. 1999, 44, $219-226$. [CrossRef]

51. Beatley, T. Envisioning Solar Cities: Urban Futures Powered By Sustainable Energy. J. Urban Technol. 2007, 14, 31-46. [CrossRef]

52. Priemus, H.; Hall, P. Multifunctional urban planning of mega-city-regions. Built Environ. 2004, 30, 338-349. [CrossRef]

53. Gallent, N.; Shoard, M.; Andersson, J.; Oades, R.; Tudor, C. Inspiring England's urban fringes: Multi-functionality and planning. Local Environ. 2004, 9, 217-233. [CrossRef]

54. Naveh, Z. Ten major premises for a holistic conception of multifunctional landscapes. Landsc. Urban Plan. 2001, 57, 269-284. [CrossRef]

55. Van Timmeren, A.; Sidler, D.; Kaptein, M. Sustainable Decentralized Energy Generation \& Sanitation: Case EVA Lanxmeer, Culemborg, The Netherlands. J. Green Build. 2007, 2, 137-150. [CrossRef]

56. Van Leeuwen, E.; Nijkamp, P.; de Noronha Vaz, T. The multifunctional use of urban greenspace. Int. J. Agric. Sustain. 2010, 8, 20-25. [CrossRef]

57. Herzog, C.P. A multifunctional green infrastructure design to protect and improve native biodiversity in Rio de Janeiro. Landsc. Ecol. Eng. 2016, 12, 141-150. [CrossRef]

58. D’Hauteserre, A.-M. Bridging the culture nature divide in Monaco. Landsc. Urban Plan. 2001, 57, $209-223$. [CrossRef] 
59. Agudelo-Vera, C.M.; Leduc, W.R.W.A.; Mels, A.R.; Rijnaarts, H.H.M. Harvesting urban resources towards more resilient cities. Resour. Conserv. Recycl. 2012, 64, 3-12. [CrossRef]

60. Codoban, N.; Kennedy, C.A. Metabolism of Neighborhoods. J. Urban Plan. Dev. 2008, 134, 21-31. [CrossRef]

61. Van Timmeren, A. Climate Integrated Design and Closing Cycles. In Sustainable Urban Environments; Springer: Dordrecht, The Netherlands, 2011; pp. 313-339. ISBN 978-94-007-1293-5.

62. Leduc, W.R.W.A.; Van Kann, F.M.G. Spatial planning based on urban energy harvesting toward productive urban regions. J. Clean. Prod. 2013, 39, 180-190. [CrossRef]

63. Baccini, P. A city's metabolism: Towards the sustainable development of urban systems. J. Urban Technol. 1997, 4, 27-39. [CrossRef]

64. Roe, M.; Mell, I. Negotiating value and priorities: Evaluating the demands of green infrastructure development. J. Environ. Plan. Manag. 2013, 56, 650-673. [CrossRef]

65. Fry, G.L.A. Multifunctional landscapes-Towards transdisciplinary research. Landsc. Urban Plan. 2001, 57, 159-168. [CrossRef]

66. Van der Hoeven, F. Landtunnel Utrecht at Leidsche Rijn: The conceptualisation of the Dutch multifunctional tunnel. Tunn. Undergr. Space Technol. 2010, 25, 508-517. [CrossRef]

67. Tress, B.; Tress, G. Capitalising on multiplicity: A transdisciplinary systems approach to landscape research. Landsc. Urban Plan. 2001, 57, 143-157. [CrossRef]

68. Lovell, S.T.; Johnston, D.M. Creating multifunctional landscapes: How can the field of ecology inform the design of the landscape? Front. Ecol. Environ. 2008, 7, 212-220. [CrossRef]

69. Rodenburg, C.A. Quantification of economic benefits of multifunctional land use-An empirical analysis among employees. J. Hous. Built Environ. 2006, 21, 69-81. [CrossRef]

70. Rodenburg, C.A.; Nijkamp, P.; De Groot, H.L.F.; Verhoef, E.T. Valuation of Multi-Functional Land Use by Commercial Investors: A Case Study on the Amsterdam Zuidas Mega-Project. Tijdschr. Econ. Soc. Geogr. 2008, 99, 454-469. [CrossRef]

71. Eijgenraam, C.; Ossokina, I. Cost-benefit analysis of railway station area development: The case of Amsterdam South Axis. In Railway Development; Bruinsma, D.F., Pels, D.E., Rietveld, P.D.P., Priemus, P.D.H., van Wee, P.D.B., Eds.; Physica-Verlag HD: Heidelberg, Germany, 2008; pp. 191-211. ISBN 978-3-7908-1971-7.

72. Paracchini, M.L.; Pacini, C.; Jones, M.L.M.; Pérez-Soba, M. An aggregation framework to link indicators associated with multifunctional land use to the stakeholder evaluation of policy options. Ecol. Indic. 2011, 11, 71-80. [CrossRef]

73. Engel-Yan, J.; Kennedy, C.; Saiz, S.; Pressnail, K. Toward sustainable neighbourhoods: The need to consider infrastructure interactions. Can. J. Civ. Eng. 2005, 32, 45-57. [CrossRef]

74. Ramaswami, A.; Weible, C.; Main, D.; Heikkila, T.; Siddiki, S.; Duvall, A.; Pattison, A.; Bernard, M. A Social-Ecological-Infrastructural Systems Framework for Interdisciplinary Study of Sustainable City Systems. J. Ind. Ecol. 2012, 16, 801-813. [CrossRef]

75. Guy, S.; Marvin, S. Constructing sustainable urban futures: From models to competing pathways. Impact Assess. Proj. Apprais. 2001, 19, 131-139. [CrossRef]

76. Fischer-Kowalski, M.; Hüttler, W. Society's Metabolism. J. Ind. Ecol. 1998, 2, 107-136. [CrossRef]

77. Minx, J.C.; Creutzig, F.; Medinger, V.; Ziegler, T. Developing a Pragmatic Approach to Assess Urban Metabolism in Europe: A Report to the European Environment Agency; TU Berlin: Berlin, Germany, 2011.

78. Kennedy, C.; Pincetl, S.; Bunje, P. The study of urban metabolism and its applications to urban planning and design. Environ. Pollut. 2011, 159, 1965-1973. [CrossRef] [PubMed]

79. Voskamp, I.M.; Spiller, M.; Stremke, S.; Bregt, A.K.; Vreugdenhil, C.; Rijnaarts, H.H.M. Space-time information analysis for resource-conscious urban planning and design: A stakeholder based identification of urban metabolism data gaps. Resour. Conserv. Recycl. 2018, 128, 516-525. [CrossRef]

80. Spiller, M.; Agudelo, C. Mapping diversity of urban metabolic functions-A planning approach for more resilient cities. In Proceedings of the 5th AESOP Young Academics Network Meeting 2011, Delft, The Netherlands, 15-18 February 2011; Delft University: Delft, The Netherlands, 2011; pp. 126-139.

81. Pandis Iveroth, S.; Vernay, A.-L.; Mulder, K.F.; Brandt, N. Implications of systems integration at the urban level: The case of Hammarby Sjöstad, Stockholm. J. Clean. Prod. 2013, 48, 220-231. [CrossRef]

82. Degeling, P. The significance of 'sectors' in calls for public health intersectoralism: An Australian perspective. Policy Politics 1995, 23, 289-301. [CrossRef] 
83. Derkzen, P.; Bock, B.B.; Wiskerke, J.S.C. Integrated Rural Policy in Context: A Case Study on the Meaning of 'Integration' and the Politics of 'Sectoring'. J. Environ. Policy Plan. 2009, 11, 143-163. [CrossRef]

84. Westerink, J. Making a Difference. Ph.D. Thesis, Wageningen University, Wageningen, The Netherlands, 2016.

85. Bressers, H.; Lulofs, K. Governance and Complexity in Water Management: Creating Cooperation through Boundary Spanning Strategies; Edward Elgar Publishing: Cheltenham, UK, 2010; ISBN 978-1-84844-955-8.

86. Opdam, P.; Westerink, J.; Vos, C.; de Vries, B. The role and evolution of boundary concepts in transdisciplinary landscape planning. Plan. Theory Pract. 2015, 16, 63-78. [CrossRef]

87. Williams, P. The Competent Boundary Spanner. Public Adm. 2002, 80, 103-124. [CrossRef]

88. Star, S.L.; Griesemer, J.R. Institutional Ecology, 'Translations' and Boundary Objects: Amateurs and Professionals in Berkeley's Museum of Vertebrate Zoology, 1907-39. Soc. Stud. Sci. 1989, 19, 387-420. [CrossRef]

89. Clark, W.C.; Tomich, T.P.; van Noordwijk, M.; Dickson, N.M.; Catacutan, D.; Guston, D.; McNie, E. Toward a General Theory of Boundary Work: Insights from the CGIAR's Natural Resource Management Programs; HKS Faculty Research Working Paper Series; John, F., Ed.; Kennedy School of Government, Harvard University: Cambridge, MA, USA, 2010.

90. Hernes, T. Enabling and constraining properties of organizational boundaries. In Managing Boundaries in Organizations: Multiple Perspectives; Palgrave Macmillan: Hampshire, UK, 2003; pp. 35-55.

91. Bijker, W.E.; Hughes, T.P.; Pinch, T.; Douglas, D.G. The Social Construction of Technological Systems: New Directions in the Sociology and History of Technology; Anniversary Edition; The MIT Press: Cambridge, MA, USA, 2012; ISBN 978-0-262-51760-7.

92. Hughes, T.P. Networks of Power: Electrification in Western Society, 1880-1930; Reprint Edition; Johns Hopkins University Press: Baltimore, MD, USA, 1993; ISBN 978-0-8018-4614-4.

93. Joerges, B. Large Technical Systems: Concepts and Issues. In The Development of Large Technical Systems; Mayntz, R., Hughes, T., Eds.; Westview Press: Boulder, CO, USA, 1988; pp. 9-36.

94. Geels, F.W. From sectoral systems of innovation to socio-technical systems: Insights about dynamics and change from sociology and institutional theory. Res. Policy 2004, 33, 897-920. [CrossRef]

95. Mulder, K.; Kaijser, A. The dynamics of technological systems integration: Water management, electricity supply, railroads and industrialization at the Göta Älv. Technol. Soc. 2014, 39, 88-99. [CrossRef]

96. Vernay, A.-L.; Mulder, K.F.; Kamp, L.M.; de Bruijn, H. Exploring the socio-technical dynamics of systems integration-The case of sewage gas for transport in Stockholm, Sweden. J. Clean. Prod. 2013, 44, 190-199. [CrossRef]

97. Ashton, W.S.; Chopra, S.S.; Kashyap, R. Life and Death of Industrial Ecosystems. Sustainability 2017, 9, 605. [CrossRef]

98. Boons, F.; Chertow, M.; Park, J.; Spekkink, W.; Shi, H. Industrial Symbiosis Dynamics and the Problem of Equivalence: Proposal for a Comparative Framework. J. Ind. Ecol. 2016, 21, 938-952. [CrossRef]

99. Vernay, A.-L.; Boons, F. Assessing Systems Integration: A Conceptual Framework and a Method. Syst. Res. Behav. Sci. 2015, 32, 106-123. [CrossRef]

100. Wu, J.; Guo, Y.; Li, C.; Qi, H. The redundancy of an industrial symbiosis network: A case study of a hazardous waste symbiosis network. J. Clean. Prod. 2017, 149, 49-59. [CrossRef]

101. Domenech, T.; Davies, M. The social aspects of industrial symbiosis: The application of social network analysis to industrial symbiosis networks. Prog. Ind. Ecol. Int. J. 2009, 6, 68-99. [CrossRef]

102. Chertow, M.R. Industrial symbiosis: Literature and taxonomy. Annu. Rev. Energy Environ. 2000, $25,313-337$. [CrossRef]

103. Korhonen, J. Industrial Ecology for Sustainable Development: Six Controversies in Theory Building. Environ. Values 2005, 14, 83-112. [CrossRef]

104. Korhonen, J. Some suggestions for regional industrial ecosystems-Extended industrial ecology. Eco-Manag. Audit. 2001, 8, 57-69. [CrossRef]

105. Yu, C.; de Jong, M.; Dijkema, G.P.J. Process analysis of eco-industrial park development-The case of Tianjin, China. J. Clean. Prod. 2014, 64, 464-477. [CrossRef]

106. Shi, H.; Chertow, M.; Song, Y. Developing country experience with eco-industrial parks: A case study of the Tianjin Economic-Technological Development Area in China. J. Clean. Prod. 2010, 18, 191-199. [CrossRef] 
107. Ashton, W. Understanding the Organization of Industrial Ecosystems. J. Ind. Ecol. 2008, 12, 34-51. [CrossRef] 108. Chertow, M.; Ehrenfeld, J. Organizing Self-Organizing Systems. J. Ind. Ecol. 2012, 16, 13-27. [CrossRef]

(C) 2018 by the authors. Licensee MDPI, Basel, Switzerland. This article is an open access article distributed under the terms and conditions of the Creative Commons Attribution (CC BY) license (http://creativecommons.org/licenses/by/4.0/). 